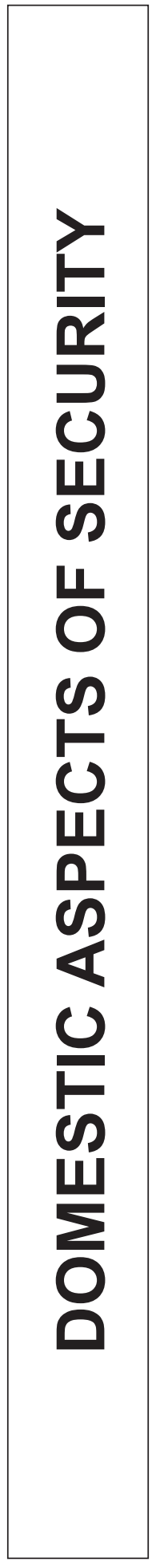





\section{INSTITUTIONAL MECHANISMS TO ENSURE NATIONAL SECURITY IN THE INFORMATION SPACE OF THE UNITED STATES, THE UNITED KINGDOM AND THE RUSSIAN FEDERATION}

\section{INTRODUCTION}

Modern world order is influenced by the multi-vector processes taking place in the information space. The centers of decision-making and launching of these processes range from transnational corporations and leading world countries to specific individuals who own information. Ensuring national security of states in the information space is linked to a wide range of issues, risks, opportunities, the use of a soft power balance and the defense system. The development strategies of G-8 countries prioritize the information direction of the national security policy, but in the transitive countries it remains almost undeveloped, which makes them extremely vulnerable to external influences.

The purpose of this article is to analyze the institutional mechanisms that ensure national security in the information space of several leading world countries. The organization of these mechanisms may become a model for many states that, despite their smaller size and capabilities of international influence, will attempt to control their information space and maintain national security in there. The system of coherence of institutional structures' actions in the development of information policy, its implementation and correction for different institutions in current conditions is of particular interest to such states.

National security can be characterized as a set of attitudes that provide definition of vital spheres of life and directions of development of the political territory (nationstate) in the internal and external political space. The concept of national security defines certain semantic constructs that allow to identify the boundaries of cooperation or competition with other political territories, as well as the boundaries of "political" claims to all or part of the political space. 
The information direction of the policy of ensure national security is interpreted in the paper as a process of strategic intentions and political practices of the state to protect national security in the information and communication space. The main task of the process is to ensure the achievement of political goals of the nation-state through the management and adjustment of political-image and political-semantic spaces.

\section{METHODOLOGICAL GROUNDS}

The information component of national security ensuring has been the subject of interdisciplinary research for half a century. Various aspects of this problem, from theoretical to applied, are covered in the works of J. Baudrillard (2010), S. Vnuchko (2012), J. Habermas (2007: 229-245), V. Horbulin (2010), L. Guberskyi (2007), S. Danylenko (2015: 303-315), K. Deutsch (1975), D. Zamyatin (2014: 20-29), Y. Komarova (2005: 97-112), V. Lipkan (2006), Y. Mahda (2017), H. Morgenthau (2000: 743-754), N. Moskalova (2016), T. Nagornyak (2013), G. Tuathail (1998), M. Polovyi (2011), G. Pocheptsov (2016), V. Prorok (2016), L. Smola (2016), N. Taleb (2014), Y. Tykhomyrova (2016), A. Toffler (2009), O. Turchenko (2013), L. Fuerth (2011).

We offer to consider the totality of political and non-political institutions, whose activities are related to ensuring full communication with target audiences in order to clarify and ensure support of national interests, as the institutional mechanisms for the implementation of the information direction of national interests ensuring. Their communication with target audiences must rely on certain conceptual bases of development and dissemination of politically relevant knowledge regarding the state, which ensures the achievement of political, economic, humanitarian and other goals. The target audience includes different segments of the population inside the respective state (including those which differ in territorial affiliation) as well as external audiences.

\section{ANALYSIS OF INSTITUTIONAL MECHANISMS TO ENSURE NATIONAL SECURITY IN THE INFORMATION SPACE OF THE UNITED STATES}

Without any doubt, the United States of America has huge experience in the information space. The United States was one of the first to recognize and put into practice systemic communications to protect, spread and cultivate their ideas, values, interests, and policies. The country now deals with the issue of synchronization of own words and actions, as well as the effective work of those responsible for disseminating knowledge about relevant territories and individuals.

The National framework for strategic communication determines that the US Government has a wide range of communication programs and activities aimed to clarify their actions, stimulate participation, inform about current political processes, influence public opinion through public diplomacy, information operations, and other procedures. The implementation of US information policy is analyzed in two directions: the first is internal communication among agencies (coordination), the second is external communication with target audiences. For effective management of internal com- 
munication in the US, there is a professional community that has been created to help state leaders and senior executives in the development and support of communications (National framework, 2015).

The unit that provides US communications with target audiences at mega- and macro- levels consists of many organizations and structures that are not limited to agencies that provide public policy, public diplomacy, military operations, and defense support for public diplomacy, planning, development, and execution of obligations.

Special attention is paid to the research, planning, and correction of the communication process, as they ensure more effective work of the responsible structures and individuals, both at the level of direct responsibilities and at the level of interagency relations. Taking into account diversified goals and objectives that governing bodies deal with and views on internal and external political, economic, humanitarian processes, the US Government puts a lot of effort to develop a common vision for the future, especially at the planning stage (National framework, 2015).

Formerly, there was an Interagency Policy Committees at the national strategic level in the United States; its main goal was to discuss and coordinate high-level communications policy. At the operational level, information policy was implemented and coordinated in two directions. The first one was the diplomatic/political The Country Team (Country Team, 2014), formed of representatives of the State Department. The second, military, was the Joint Interagency Coordination Group. The Country Team implements communication policy globally, and the Joint Interagency Coordination Group consults and corrects communications in light of the strategic and operational situation around national security and defense (National framework, 2015).

The United States actively uses public-private partnerships for effective implementation of information policy. This direction of activity is widely used in research, consulting, and implementation of specific communication projects. Due to these partnerships, the US governing bodies obtain broader and more comprehensive information on issues of interest, and, in addition, use partners' intellectual, financial and reputational capital, creating a synergetic effect for the achievement of strategic goals (in the context of this research - the formation of loyalty capital) (National framework, 2015).

At the operational level of the implementation of US information policy, roles and responsibilities are shared among key US government institutions. US National Security Staff ensures control over the implementation of information policy on compliance with the fundamental goals and objectives of national security, promotes the establishment and security of communications in «problem» regions.

U.S. Department of States ensures the implementation of a communication policy to disseminate knowledge regarding US interests to internal audiences (citizens and resident organizations) and to communicate with external target audiences through traditional and public diplomacy. The United States Department of Defense ensures information operations and support for public diplomacy, public policy, and internal affairs.

The U.S. Agency for Global Media (USAGM) is responsible for non-military/civil international broadcasting under US auspices. The structure provides broadcasting through radio, television, the Internet and other new media in 60 languages and reaches 175 million people worldwide. The main purpose of the Agency is to provide target 
audiences with news and information from their own and independent sources. The United States Agency for International Development (USAID) supports communication with target groups through humanitarian programs and projects, both inside and outside of the United States. USAID also works on building capacity (loyalty capital), including media development and training of media specialists.

Besides, the Intelligence Community actively participates in the implementation of the information and communication policy; they support the analytical basis of information policy, monitor open and hidden public opinion, provide consultations, tools, and methods for the work with target groups, giving special attention to public diplomacy (National framework, 2015: 7-12).

How the US Government treats strategic communications is crucial to protecting national interests and achieving political, economic and humanitarian goals. Based on the official documents, we can conclude that communications are part of a management system that provides competitiveness in the information space, a high level of trust and growth of US loyalty capital. Special attention is also paid to the professional training and culture of strategic communications among civil servants (Update to Congress, 2012).

\section{THE STRUCTURE OF INSTITUTIONS TO ENSURE NATIONAL SECURITY IN THE INFORMATION SPACE AT THE UNITED KINGDOM}

Similar to the United States of America, the United Kingdom has extensive experience in the organization and implementation of strategic communications with the aim to promote and protect its national interests and strategic goals. Despite the high level of specialists' training, long-standing traditions and understanding of the necessity of these communications, there is constant work to improve this area of activity.

In 2010 and 2014, the structure of UK strategic communications underwent significant restructuring. Emphasis was placed on strengthening of central coordination, efficiency and adequate costs for the implementation of communication policy. The principles of work were dramatically changed.

In 2010-2013, the entire UK communication was concentrated around the work of the Government Communication Centre; it was included in the Cabinet of Ministers and bore responsibility for proactive government communication. Its job was to work with communication hubs and agencies and to provide assistance in solving common problems (UK Government, 2013: 18).

During that period, Communication hubs were founded to facilitate cooperation and create conditions for the interaction of different agencies or bodies, which establish communications with common target audiences. Thus, there were seven centers for the establishment of government communications (UK Government, 2013: 53); they used to consolidate similar areas of activity and target audiences and work in close collaboration with multiple departments. These hubs provided government agencies with advice and offered optimal methods and tools for communication with their target audiences, as well as helped to uncover the professional communication potential of the relevant bodies (UK Government, 2013: 16). 
The Government Communication Centre and Communication hubs were supposed to ensure and support:

- suggestions of agencies and their organizations regarding early planning of communications, media planning and media buying, including interaction with organizations that provide such services and purchasing information placements in mass media;

- consulting and evaluation, including in the issues of planning, implementation or ordering of communication assessment projects;

- placement of publicly important information on health, well-being, and safety on radio and TV channels, including on digital and satellite media;

- daily monitoring of the media and preparation of information digest for all state agencies and organizations;

- regional press offices of state agencies and organizations in the regions through the Regional News Network, as well as regional researchers who provide new knowledge, briefs, and media monitoring for regional visits of high-level ministers (UK Government, 2013: 18-19).

The Government Digital Service was established to provide services of digital nature. The Service develops and supports websites and blogs of state bodies and their structural units. The Service is actively cooperating with the Government Communication Centre to provide analytical information on requests received through digital channels. This information has been actively used to correct and develop communication activities.

Since 2014 to the present, the Government Communication Service is the main institution that provides all communications. Its purpose is to ensure effective government communications in the context of the information direction of the policy of national interests' protection in the following strategic areas:

- economic security (attracting investments, information and marketing support for British companies abroad, etc.);

- national security protection (information and communication support of the security forces and the army, fight against negative impact on the moods and behavior of British citizens, support for military and defense policy, etc.);

- assistance in the implementation of domestic policy (implementation of reforms, resolution of pressing domestic issues, etc.). Special attention is paid to the support of EU policies and public diplomacy (Government Communications, 2016: 7).

The Service is implementing a step-by-step reform of the communication system to increase the level of its efficiency and for the economic effect. The first three stages (from January 2014 to August 2016) were directed towards a conceptual rethinking of the government communications system, taking into account new challenges, such as:

- aggressive information policy of the Russian Federation and ISIS, the situation in the EU, BREXIT;

- resolution of a human resource issue, which should provide workforce capable to adequately and quickly respond to contemporary challenges;

- realignment of the government communications structure and elaboration of a modern communication model (The Modern Communications Operating Model (MCOM)); 
- establishing horizontal and vertical channels of communication between governmental agencies and local authorities (Improving GCS, 2016; compare: Improving government, 2020).

The fourth stage (August 2016 to date) focuses on the development of unified approaches to information campaigns involving a wide range of stakeholders, partners, and national brands; implementation of modern approaches to interaction with the media, including digital media; improvement of professional qualification of officials; development of cross-sectoral cooperation with the engagement of a wide range of people interested in the intensification and effectiveness of government communications at national and regional levels, and the development of strong networking practices (Improving GCS, 2016).

The expected results of the government communications are behavioral changes beneficial to individuals and society; operational efficiency of public services; high reputation of the UK and crisis response in the context of possible reputational losses to the country; understanding of the Government policies and programs by target audiences (The Government Communication, 2015).

It should be noted that the Ministry of Information Policy of Ukraine has been actively studying and trying to implement the UK experience in the organization of government communications (MIP: Dosvid, 2015).

According to the Action plan to improve communicating Europe by the Commission (Action plan, 2015), the body that provides communication of the European Commission as the EU's official governing body consists of several units.

Directorates-General for Communication is responsible for informing and communicating European Union policies to the general public (About us, 2015). DirectoratesGeneral mainly works through mass media, opinion leaders, presentation commissions (contact centers) and information networks in the EU Member States. It is responsible for informing the Commission on trends in public opinion, media, and political events, and coordination of communication activities in the framework of the structural units of the European Commission.

Directorates-General for Communication together with the contact centers in the Member States, implement the following functions:

- defines and controls the corporate image of the Commission;

- makes suggestions, plans, and implements communication projects of the Commission for the general public based on political priorities and citizens' interests;

- communicates regarding other topics of political importance and public interest, helps citizens to find out about all EU related issues;

- provides corporate tools and communication skills to other Offices following their strategies and communication relations;

- consults on the most efficient use of communication resources throughout the Commission;

- manages common tools and communication projects in partnership with other institutions and Member States as needed;

- informs the Commission on public opinion and reputational risks in the Member States, provides political coverage of events in the EU countries;

- helps to evaluate all communication activities of the Commission (About us, 2015). 
Since 2016, the construction of a single architecture of the communication system has been defined as a priority (Communication Policy, 2016).

The Spokesperson's Service works under the political control of the President of the Commission and in cooperation with its agencies. The Service informs and responds to media inquiries about EU policies and activities and acts as the official speaker of the European Commission. It represents a coherent media policy and coordinates individual press secretaries; refutes data that contains false and distorted information, develops media strategy for members of the European Commission, plans communications with the press, taking into account the strategic and political priorities of the President and the Commission (What we do, 2016).

At the regional level, the implementation of the communication policy is exercised by Commission Representations in Member States. They provide information about the European Union through events and distribution of information (brochures, leaflets and other materials). There are information hubs where local residents can obtain information by phone or email and, if necessary, visit local information events.

The European Public Spaces ensures communication through events on European issues that are open to the general public in Member States. The European Commission together with the European Parliament have founded joint helpdesks where people can obtain the necessary information. In addition, the European Public Spaces organize and coordinate debates, forums, lectures and training on European issues, as well as cultural events such as exhibitions and film screenings (EU Local, 2015).

Representations of the European Commission in the Member States focus their activities on information and communication services. Besides, Representations have crucial importance for bilateral communication between the Commission and the Member States, acting as an intermediary between them and collecting information in the field. Update of the Representations' digital presence in all areas of activity will involve investment in training and hardware, including for communication online. Activity in social networks should become one of the main communication channels for Representations, complementing their political, media, and educational activities. Support of a local approach to messages developed in the center and establishing contacts with local experts should help to expand the media pool with social networks, blogs, etc., and opportunities of Representations' employees (Strategic Plan, 2016).

At the global level, there is the European External Action Service responsible for the network of around $140 \mathrm{EU}$ offices located outside the Union. Its delegations serve as the main communicator and speaker of the European Union abroad. The purpose is to make the EU's external influence more consistent and effective, which will globally increase the influence of the European Union. The EEAS works in cooperation with the diplomatic services of the Member States and includes officials from the relevant departments of the General Secretariat of the Council of the European Union and the European Commission, as well as staff delegated by national diplomatic services of the EU Member States (EU in, 2019).

The issue of effective use of strategic communications in NATO's activity has always been at the top of the agenda. But it has come on a systemic level after problems with the public support for Alliance actions during a military operation in Afghanistan. 
As Ukrainian researcher A. Barovska writes "from the start of the campaign in Afghanistan, numerous communication measures were taken and [psychological] influence was exercised; however, the issue of a comprehensive communication strategy to coordinate various activities and messages was not raised. In the implementation of information and communication activities, insufficient attention was paid to global public opinion, as the efforts were focused mainly on audiences in Afghanistan itself. As a result, for a long time, for the American public, in particular, it was unclear what had exactly happened in Afghanistan and whether the mission had succeeded; psychological campaigns were primarily aimed at supporting military operations, and therefore, the messages were targeted primarily at civilians with the aim to separate them from the Taliban and, thus, preventing their support of the Taliban in the conflict" (Barovska, 2015: 149). At the same time, the importance of the local population was practically disregarded, and the purpose of those messages was narrowed down to the need to eliminate terrorists.

In March 2007, the Office of Strategic Communications was established. The initiative was taken over by NATO's political headquarters in Brussels, where the Public Diplomacy Division immediately attached strategic communications to its list of key tasks. Shortly after that, the first strategic communications documents were adopted. An unpublished NATO report of May 2007 acknowledged that strategic success in Afghanistan depends on the political will of the participating countries. According to this document, international awareness of the importance of the mission in Afghanistan is vital to its success. Since then, all Alliance structures have become more active on Twitter, Facebook, Flickr and YouTube, and now they have a website and a TV channel, and work with apps for iPhone (Barovska, 2015: 150). In order to counteract the Taliban propaganda, videos and images of NATO operations have been declassified and open to the public. As a consequence, the increasing number of images taken during operations by military video groups, helmet-mounted cameras, or from airborne platforms gives the possibility to refute unfounded claims of the Taliban. On 31 October 2007, a directive on Enhancing NATO's Strategic Communications was adopted, and one year later another directive on Strategic Communication was issued by Headquarters of NATO Commander-in-Chief in Europe, which emphasized the need for appropriate support. And in 2008, the issue of strategic communications was reflected in the Alliance's political document - the NATO Bucharest Summit Declaration (Barovska, 2015: 150).

NATO strategic communications, that promote and protect the interests of the Alliance, are implemented by:

The Committee on Public Diplomacy (CPD) serves the North Atlantic Council (NAC) as the advisory body on communications, media, and public exchanges. It gives recommendations to the NAC on how to encourage the public to understand and support NATO's goals. In this regard, the Committee is responsible for planning, implementing and evaluating NATO's public diplomacy strategy.

In support of their goals, CPD members share their own experience of national information and communication programs and perception of the Alliance and its activities by target audiences. The CPD discusses, develops and advises on information strategy and communications. 
The CPD was founded in 2004, then it became the Committee on Information and Cultural Relations (CICR), one of the first NATO committees that systematically used information and communication technologies to promote and protect the interests of the Alliance (Committee on Public, 2019).

The overall aim of NATO's communications activities is to facilitate dialogue and understanding, while simultaneously informing the general public and engaging them to an ongoing security discussion.

For this, NATO cooperates with the media, develops programs of communication and public diplomacy for specific target groups, including opinion leaders, academics and parliamentary groups, youth and education circles. The Alliance aims to reach worldwide audiences through various platforms and activities on social networks, disseminating materials and implementing programs and activities with external partners (Communications and, 2016).

The mission of NATO Strategic Communications Centre of Excellence («StratComm») is to promote the process of NATO capacity development, increase efficiency of missions and establish and support strategic communications. The aim of the Centre is to increase the potential of NATO's strategic communications. The Centre works as a research institution and a testing facility for new ideas and approaches (Annual Report, 2015: 3). The Centre is responsible for drafting of strategic documents and experimental developments in the field of strategic communications (Doctrine, Concept and Experimentation Branch), educational and professional training (the Education and Training Branch), implementation of operational information and communication activities (the Operational Support Branch) and support of national governments of NATO Member States (Annual Report, 2015: 4).

\section{THE MAIN OFFICIAL INSTITUTIONS FOR ENSURE NATIONAL SECURITY IN THE INFORMATION SPACE OF THE RUSSIAN FEDERATION}

In the context of this study, the main official institutions that implement information policy of the Russian Federation are the President, the Government, the Security Council, Federal executive bodies, interagency and state commissions, executive bodies of federal subjects, bodies of local self-government, public associations (Doctrina informacionnoi, 2000), mass media and new (social) media.

There is Presidential Office of Public Relations and Communications in the Russian Federation. Its main tasks are to ensure the implementation of the constitutional Presidential powers in the field of state information policy, as well as to elaborate suggestions to the President on state information policy and to participate, on behalf of the President, in the implementation of these suggestions; to analyze media and public opinion on the implementation of state policy in different areas and promptly inform the President about it; to develop a strategy of information support of socially important decisions, as well as to participate, on behalf of the President, in their implementation; to coordinate information work of federal state and executive authorities with the aim of unbiased coverage of state policy in the media; to coordinate information support of major international events in the Russian Federation and abroad (Ukaz "Ob Upravlenii, 2012). 
The implementation of the information policy of the Government of the Russian Federation is the responsibility of press service, which main tasks are: information support of the Government's activity; organization and sustentation of relations between the Prime Minister of the Russian Federation and the Deputy Prime Minister of the Russian Federation and the media; implementation of state policy and regulation in the field of mass media, mass communication, publishing and printing activities; implementation of state policy in the field of culture and cinematography; implementation of state policy on creation of the country's positive image abroad; coordination of the press services of federal executive bodies. Moreover, it coordinates the activities of the following units of the Government Office: the Department of Government's Press Service and Information; the Department of Speechwriting for Public Addresses of Prime Minister; and the Department of Culture (Structura Pravitelstva, 2020).

Though the President and the Government of the Russian Federation define fundamental strategic priorities, coordinate the development and implementation of information policy, the main job and responsibilities lie on state federal authorities (ministries, departments, and organizations), executive bodies of the federal subjects and local self-government bodies.

Thus, the information policy of such ministries as the Ministry of Foreign Affairs, Ministry of Economic Development, Ministry of Digital Development, Communications and Mass Media of the Russian Federation is of high research interest.

Information policy in the framework of the Ministry of Foreign Affairs work is implemented to facilitate the priorities of Russia's foreign policy, considering its growing responsibility for shaping the international agenda and the foundations of the international system. Information policy ensures clarification of the Russian Federation's international policy, establishing strong and authoritative positions as one of the most influential and competitive world centers.

An important direction of foreign policy activity of the Russian Federation is the protection and promotion of its national interests (Koncepcija vneshnei, 2016). As the Concept of the Foreign Policy of the Russian Federation states, in order to ensure national interests and to achieve national strategic priorities of the Russian Federation, the foreign policy of the state aims to fulfill the next fundamental tasks:

- to ensure the country's security, sovereignty, and territorial integrity, strengthening of democratic institutions and the rule of law;

- to create favorable external conditions for sustainable growth and increased competitiveness of the Russian economy and its technological renovation; to raise the standard and quality of life of the population;

- to strengthen the position of the Russian Federation as one of the most influential centers of the modern world;

- to enhance the position of the Russian Federation in the system of world economic relations, prevention of discrimination of Russian goods, services, investments, use of opportunities of international and regional economic and financial organizations (Koncepcija vneshnei, 2016);

- to promote the strengthening of international peace, ensuring universal security and stability with the aim of establishing a fair democratic international system based on collective principles for solving international problems, the rule of international 
law, the provisions of the Charter of the United Nations, and on equal rights and partnership relations between states under the central coordinating role of the United Nations as the main organization regulating international relations;

- to develop good neighborly relations with neighboring states, facilitating the elimination of existing tensions and conflicts in their territories and prevention of such outbreaks and conflicts (Koncepcija vneshnei, 2016);

- to develop bilateral and multilateral relations of mutually beneficial and equal partnership with foreign states, intergovernmental organizations, international organizations, and to defend national priorities within international forums based on respect for the principles of independence and sovereignty, pragmatism, transparency, predictability, and non-confrontation; to expand international cooperation on a non-discriminatory basis, assistance in the formation of network alliances, and Russia's active participation in them (Koncepcija vneshnei, 2016).

Ministry of Digital Development, Communications and Mass Media of the Russian Federation is the federal executive body responsible for the development and implementation of public policy and legal regulation of information technology (including the use of information technology in the formation of state information resources and providing access to them), telecommunications (including the use and conversion of radio frequency spectrum) and mail; and in the field of mass communications and media, including the development of the Internet, television (and digital broadcasting), new technologies, printing, publishing, and personal data processing (Structura ministerstva, 2020). The Ministry coordinates and controls the activities of the Federal Service for Supervision in the Sphere of Mass Communications, the Federal Communications Agency, the Federal Agency for Press and Mass Communications (Structura ministerstva, 2020).

\section{CONCLUSIONS}

Taking into consideration further growth in the effectiveness of information and communication impact on states and social communities, the world's leading nations continue to increase their intellectual and technological capacity to ensure national security in the information space.

Actually, institutional mechanisms that ensure national security in the information space of the countries considered afore have a similar structure. The main components of these mechanisms are: public authorities (state leaders (president or prime minister), government, ministries, and agencies), local self-government bodies, institutions of civil society, academic community, business community, media. Generalized models of functioning of different institutional structures aimed to ensure national security in the information space in contemporary leading states are discussed in another paper of the authors (Bondarenko, Nagornyak, Polovyi, 2018: 44-54).

The analysis of regulatory framework on national security protection of the USA, Great Britain, and the Russian Federation demonstrates the gradual expansion of the system of institutions that ensure national security in the information space and increase of their powers. 
The conducted analysis also demonstrates the paradigm shifts in the development and implementation of US and UK information policy in the context of modern nonlinear processes. Paradigmatic shifts are currently reorienting towards the interests and needs of target audiences, diversification of channels and mechanisms of meaning distribution (strategic narratives) in the information space, from vertical to horizontal interaction with internal and external audiences. Emphases are shifting to the involvement of a wide range of institutions and other stakeholders in the implementation of information policy, delegation of powers from the center to the periphery while preserving main parameters of policy established by state structures (compliance with strategic goals and objectives, focus on the stability of the political system, etc.).

The synergetic specificity of the policy of ensure national security in the nonlinear development of the world is due to the development of post-information society, post-privateity, loss of monopoly on the production and dissemination of collective meanings by "traditional" institutions of power, increasing decision-making centers, unbalanced political systems. All this creates the conditions for changing the traditional hierarchical system of institutional mechanisms of ensure national security in the information space.

\section{REFERENCES}

About us. Departments (Directorates-General) and services. Communication, European Commission, http://ec.europa.eu/dgs/communication/about/index_en.htm (22.03.2015).

Action plan to improve communicating Europe by the Commission, EUR-Lex, http://europa. eu/legislation_summaries/institutional_affairs/decisionmaking_process/110102_en.htm (22.03.2015).

Annual Report (2015), Annual Report for the period from 1 January 2015 to 31 December 2015, NATO Strategic Communications Centre of Excellence, https://www.stratcomcoe.org/download/file/fid/5462 (28.05.2016).

Barovska A. V. (2015), Strategichni kommunikacii: dosvid NATO, „Strategichni prioriteti”, No. 1.

Baudrillard J. (2010), Simulacra and simulation, Univ. of Michigan Press, Ann Arbor, Mich.

Bondarenko S., Nagornyak T., Polovyi M. (2018), Modern information models of the national interests' protection policy of the world countries, „European journal of transformation studies”, Vol. 6, Iss. 2.

Committee on Public Diplomacy (CPD), NATO, http://www.nato.int/cps/en/natohq/topics_69272. html (29.08.2019).

Communication Policy \& Strategy, European Commission, http://ec.europa.eu/ipg/basics/policy/index_en.htm (19.03.2016).

Communications and public diplomacy, NATO, http://www.nato.int/cps/en/natohq/topics_69275. htm (27.07.2016).

Country Team, U.S. Department of States, http://www.state.gov/courses/rs401/page_25.htm (14.12.2014).

Danylenko S. Y. (2015), Mental'no-kul'turnye y polytycheskye posledstvyya ynformatsyonnoy ahressyy Rossyy protyv Ukrayny y puty ee preodolenyya, „Problemy mizhnarodnykh vidnosyn”, Iss. 10-11, http://nbuv.gov.ua/UJRN/Pmv_2015_10-11_24 (25.05.2017). 
Deutsch K. W. (1975), The nerves of government: models of political communication and control, 5th pr. [of the rev. ed.], New York.

Doktrina informatsionnoy bezopasnosti (2000), Doktrina informatsionnoy bezopasnosti Rossiyskoy Federatsii, 9 sentyabrya 2000 g. No. PR-1895, Femida.info, http://www.femida. info/14/19002.htm (22.03.2015).

$E U$ in the World, European External Action Service, https://eeas.europa.eu/headquarters/headquarters-homepage/area/geo_en (02.08.2019).

EU Local offices and information points, European Commission, http://ec.europa.eu/contact/local_ offices_en.htm (12.01.2019).

Fuerth L. (2011), Operationalizing Anticipatory Governance, „Prism”, Vol. 2, No. 4, http://cco.ndu. edu/Portals/96/Documents/prism/prism_2-4/Prism_31-46_Fuerth.pdf (22.03.2015).

Government Communications Plan 2016/17, Government Communication Service, https:/gcs.civilservice.gov.uk/wp-content/uploads/2017/08/6.3149_CO_GCS-Comms-Plan_FINAL_WEB. $\operatorname{pdf}(12.09 .2017)$.

Horbulin V. P., Kachyns'kyy A. B. (2010), Stratehichne planuvannya: vyrishennya problem natsional'noyi bezpeky, Kyyiv.

Hubers'kyy L. V., Kamins'kyy Y. Y., Makarenko Y. A., Ozhevan M. A., Shnyrkov O. I. (2007), Informatsiyna polityka Ukrayiny: yevropeys'kyy kontekst, Kyyiv.

Improving GCS, Government Communication Service, https://gcs.civilservice.gov.uk/about-us/improving-ges/ (11.04.2019).

Improving government communications: GCS 2020, https://gcs.civilservice.gov.uk/about-us/gcs$2020 /(17.01 .2020)$.

Khabermas Y. (2007), Teoriya kommunikativnogo deystviya (Fragmenty), „Voprosy sotsial'noy teorii", Vol. 1, Iss. 1.

Komarova Y. U. (2005), Deyakí aspekti analizu strukturnoï samoorganizatsiï politichnoï sistemi, „Polítichniy menedzhment”, No. 1.

Kontseptsiya vneshney politiki (2016), Kontseptsiya vneshney politiki Rossiyskoy Federatsii, 30 noyabrya 2016, Ministerstvo inostrannykh del Rossiyskoy Federatsii, http://www.mid.ru/ foreign_policy/news/-/asset_publisher/cKNonkJE02Bw/content/id/2542248 (15.12.2019).

Lipkan V. A. (2006), Teoretychni osnovy ta elementy natsional'noyi bezpeky Ukrayiny, Kyyiv.

Mahda Y. E. (2017), Hibrydna ahresiya Rosiyi: uroky dlya Yevropy, Kyyiv.

MIP: Dosvid Uryadu Velykobrytaniyi bude vykorystano pid chas reformy systemy derzhavnykh komunikatsiy (2015), Ministerstvo informatsiynoyi polityky Ukrayiny, 21 hrudnya, http://mip. gov.ua/news/866.html (17.10.2016).

Morgenthau G. (2000), Politicheskiye otnosheniya mezhdu natsiyami. Bor'ba za vlast' $i$ mir, in: Politologiya: khrestomatiya, (eds.) M. A. Vasilik, Moskva.

Moskal'ova N. (2016), Kontseptsiyi natsional'noho interesu v naukoviy literaturi, „Visnyk Donets'koho natsional'noho universytetu. Seriya politychni nauky", No. 1, http://jvestnikpolitology.donnu.edu.ua/article/view/3931/3964 (17.10.2016).

Nahornyak T. L. (2013), Brendynh terytoriy yak derzhavna ta rehional'na polityka, Donets'k.

National framework for strategic communication, Federation of American Scientists, http://www.fas. org/man/eprint/pubdip.pdf (15.07.2015).

Ob Upravlenii (2012), Ob Upravlenii Prezidenta Rossiyskoy Federatsii po obshchestvennym svyazyam i kommunikatsiyam, Ukaz Prezidenta Rossiyskoy Federatsii No. 876, http://www.kremlin.ru/ref_notes/1242 (16.07.2019).

Pocheptsov H. (2016), Smysly i viyny: Ukrayina i Rosiya v informatsiyniy i smysloviy viynakh, Kyyiv. 
Polovyi M. A. (2011), Politichni procesi: teorija ta praktika modeluvannja, Odesa.

Prorok V. (2016), Teoriya khaosa i teoriya setey - novyye podkhody k modelirovaniyu politicheskoy sistemy, „PolitBook”, Vol. 1.

Smola L. Y. (2016), Aspekty vedennya informatsiynoyi ta hibrydnoyi viyny v konteksti zastosuvannya komunikatsiynykh tekhnolohiy, ,S.P.A.C.E. Society, Politics, Administration in Central Europe: elektronnyy naukovo-praktychnyy zhurnal", Iss. 1.

Strategic Plan (2016), Strategic Plan 2016-2020 DG communication, European Commission, https://ec.europa.eu/info/sites/info/files/strategic-plan-2016-2020-dg-comm_april2016_ en.pdf (25.08.2016).

Struktura Ministerstva, Ministerstvo tsifrovogo razvitiya, svyazi i massovykh kommunikatsiy Rossiyskoy Federatsii, https://digital.gov.ru/ru/ministry/structure/ (10.01.2020).

Struktura Pravitel'stva RF. Raspredeleniye obyazannostey v rukovodstve Apparata Pravitel'stva, Pravitel'stvo Rossii, http://government.ru/office/responsibilities/ (15.01.2020).

Taleb N. (2014), Antikhrupkost'. Kak izvlech'vygodu iz khaosa, Moskva.

The Government Communication Service: an introduction, Government Communication Service, https:/gcs.civilservice.gov.uk/wp-content/uploads/2015/08/About-the-Government-Communication-Service.pdf (13.08.2019).

Toffler E. (2009), Metamorfozy vlasti: Znaniye, bogatstvo i sila na poroge XXI veka, Moskva.

Tuathail Gearóid Ó. (1998), Postmodern geopolitics? The modern geopolitical imagination and beyond, in: Rethinking Geopolitics, (eds.) S. Dalby, G. O. Tuathail, London.

Turchenko O. H. (2013), Shchodo identyfikatsiyi katehoriy «interes» ta «natsional'nyy interes» yak ob'yektiv zabezpechennya bezpeky, „Pravnychyy chasopys Donets'koho universytetu”, No. 1.

Tykhomyrova Y. B. (2016), Rehional'na polityka Yevropeys'koho Soyuzu: informatsiyno-komunikatsiynyy aspekt, in: Rehional'ni stratehiyi SSHA i Yevropy: zovnishn'opolitychnyy i bezpekovyy vymir, Kyyiv.

UK Government Communications Plan 2013/14, Government Communication Service, https://gcs. civilservice.gov.uk/wp-content/uploads/2015/09/GOVCOMMSPLAN2014.compressed.pdf (17.02.2019).

Update to Congress on National framework for strategic communication, Mountainrunner, US, http://mountainrunner.us/files/2012/03/President-response-to-NDAA-1055-of-2009.pdf (15.07.2018).

Uryad pidtrymav Kontseptsiyu reformy uryadovykh komunikatsiy, rozroblenu Ministerstvom informatsiynoyi polityky Ukrayiny (2016), Ministerstvo informatsiynoyi polityky Ukrayiny, 20 sichnya, http://mip.gov.ua/news/890.html (04.05.2016).

Vnuchko S. M. (2012), Politychnyy prostir v hlobal'nomu vymiri, „Visnyk Kyyivs'koho natsional'noho universytetu imeni Tarasa Shevchenka", Iss. 107.

What we do. Departments (Directorates-General) and services. Communication, European Commission, http://ec.europa.eu/dgs/communication/about/what_we_do/index_en.htm (16.06.2016).

Zamyatin D. N. (2014), Prostranstvo i dvizheniye, „Sotsiologicheskiye issledovaniya”, No. 4.

\begin{abstract}
The paper is devoted to an analysis of the institutional mechanisms that ensure national security in the information space of several leading countries - the United States, the United Kingdom and the Russian Federation. It is stated that institutional mechanisms that ensure national security in the information space of the leading countries all have a similar structure. The
\end{abstract}


main components of these mechanisms involve public authorities (state leaders - president or prime minister, government, ministries, and agencies), local government bodies, civil society institutions, the academic community, business community, and the media. The gradual expansion of the system of institutions that ensure national security in the information space and increase in their powers occurs in all these states. The analysis also demonstrates the paradigm shifts in the development and implementation of US and UK information policy in the context of modern nonlinear processes. Paradigmatic shifts are currently being reoriented towards the interests and needs of target audiences, diversification of channels and mechanisms of the distribution of meaning (strategic narratives) in the information space, from vertical to horizontal interaction with internal and external audiences. Emphases are shifting to the involvement of a wide range of institutions and other stakeholders in the implementation of information policy and delegation of powers from the center to the periphery, while preserving the main parameters of the policy established by state structures.

Keywords: ensure national security, information space, institutional mechanisms, United States, United Kingdom, Russian Federation

\section{INSTYTUCJONALNE MECHANIZMY ZAPEWNIENIA BEZPIECZEŃSTWA NARODOWEGO W PRZESTRZENI INFORMACYJNEJ STANÓW ZJEDNOCZONYCH, WIELKIEJ BRYTANII I FEDERACJI ROSYJSKIEJ}

\section{STRESZCZENIE}

Artykuł poświęcony jest analizie mechanizmów instytucjonalnych zapewniających bezpieczeństwo narodowe w przestrzeni informacyjnej kilku najważniejszych państw świata - Stanów Zjednoczonych, Wielkiej Brytanii i Federacji Rosyjskiej. Stwierdzono, że mechanizmy instytucjonalne zapewniające bezpieczeństwo narodowe w przestrzeni informacyjnej państw będących liderami światowymi mają podobną strukturę. Główne składowe tych mechanizmów obejmują władze publiczne (przywódcy państw - prezydent lub premier, rząd, ministerstwa i agencje), organy samorządu terytorialnego, instytucje społeczeństwa obywatelskiego, środowiska akademickie, biznesowe i media. We wszystkich analizowanych państwach następuje stopniowa rozbudowa systemu instytucji zapewniających bezpieczeństwo narodowe w przestrzeni informacyjnej oraz zwiększanie ich uprawnień. Przeprowadzona analiza ukazuje również zmiany paradygmatu w zakresie tworzenia i wdrażania polityki informacyjnej Stanów Zjednoczonych i Wielkiej Brytanii w kontekście nowoczesnych procesów nieliniowych. Obecne zmiany paradygmatów oznaczają przeorientowanie na interesy i potrzeby odbiorców docelowych, dywersyfikację kanałów i mechanizmów dystrybucji znaczeń (narracje strategiczne) w przestrzeni informacyjnej, od interakcji pionowej do poziomej z odbiorcami wewnętrznymi i zewnętrznymi. Akcent przenosi się na zaangażowanie szerokiego grona instytucji i innych interesariuszy w realizację polityki informacyjnej i delegowanie uprawnień z centrum na peryferie, przy zachowaniu głównych parametrów polityki ustalonych przez struktury państwowe.

Słowa kluczowe: zapewnienie bezpieczeństwa narodowego, przestrzeń informacyjna, mechanizmy instytucjonalne, Stany Zjednoczone, Wielka Brytania, Federacja Rosyjska 
